\title{
EVOLUTION OF THE MICROSTRUCTURE AND MAGNETIC PROPERTIES OF A COBALT-SILICON-BASED ALLOY IN THE EARLY STAGES OF MECHANICAL MILLING
}

\author{
RAZVOJ MIKROSTRUKTURE IN MAGNETNIH LASTNOSTI \\ ZLITINE Co-Si V ZAČETNEM STADIJU MEHANSKEGA \\ LEGIRANJA
}

\author{
Watcharee Rattanasakulthong ${ }^{1}$, Chitnarong Sirisathitkul ${ }^{2}$, Peter Franz $\mathbf{R o g l}^{3}$ \\ ${ }^{1}$ Department of Physics, Faculty of Science, Kasetsart University, Bangkok, Thailand \\ ${ }^{2}$ Magnet Laboratory, Molecular Technology Research Unit, School of Science, Walailak University, Nakhon Si Thammarat, Thailand \\ ${ }^{3}$ Institute of Materials Chemistry and Research, University of Vienna, Vienna, Austria \\ chitnarong.siri@gmail.com
}

Prejem rokopisa - received: 2014-12-11; sprejem za objavo - accepted for publication: 2014-12-22

doi: $10.17222 /$ mit. 2014.300

\begin{abstract}
The early stages in the mechanical alloying of amount fractions $x=40 \%$ cobalt (Co) and $x=60 \%$ silicon (Si) powders were investigated using X-ray diffractometry (XRD), scanning electron microscopy (SEM), differential thermal analysis (DTA) and vibrating-sample magnetometry (VSM). After 2-8 h of ball-milling, the characteristic XRD peaks of the face-centered-cubic (fcc) $\mathrm{Si}$ and hexagonal close-packed (hcp) Co phases remained sharp without a cobalt-silicide phase. As the milling progressed, the particle size observed by SEM tended to reduce, being accompanied by smoother edges and a narrow size distribution. On the DTA curves, between $200{ }^{\circ} \mathrm{C}$ and $1200{ }^{\circ} \mathrm{C}$, exothermic peaks indicated a ferromagnetic-to-paramagnetic transition, whereas endothermic peaks corresponded to the lattice recovery, the transition from a hep to a fcc Co and melting. The longest milling of up to $8 \mathrm{~h}$ significantly increased the magnetic squareness and the coercive field.
\end{abstract}

Keywords: Co-Si alloys, ball milling, XRD, VSM, DTA

Preiskovan je bil začetni stadij mehanskega legiranja zlitine, sestavljene iz prahov z množinskim delom $x=40 \%$ kobalta (Co) in $x=60 \%$ silicija $(\mathrm{Si})$. Uporabljena je bila rentgenska difraktometrija (XRD), vrstična elektronska mikroskopija (SEM), diferencialno termična analiza (DTA) in vibracijska magnetometrija vzorcev (VSM). Po mletju od $2 \mathrm{~h}$ do $8 \mathrm{~h}$ v krogličnem mlinu so še ostali ostri značilni XRD-vrhovi faz fcc Si in hcp Co brez Co-silicidne faze. S podaljševanjem časa mletja se s SEM opazi zmanjšanje velikosti delcev prahov, zožanje njihove velikostne porazdelitve in povečanje zaobljenja robov delcev. Na DTA-krivuljah se je med $200{ }^{\circ} \mathrm{C}$ in $1200{ }^{\circ} \mathrm{C}$ pojavil eksotermni vrh, ki je posledica prehoda iz feromagnetne v paramagnetno fazo, endotermni vrh pa je posledica poprave rešetke zaradi prehoda iz hcp v fcc Co in nato taljenja. Najdaljši časi mletja (do 8 h) pomembno vplivajo na magnetno koercitivnost in povečanje kvadratičnosti histerezne zanke.

Ključne besede: zlitina na osnovi Co-Si, kroglično mletje, XRD, VSM, DTA

\section{INTRODUCTION}

Mechanical milling has been successfully used in producing a variety of magnetic amorphous alloys, intermetallic compounds, nanocomposites and nanocrystalline powders. ${ }^{1,2}$ Milling ferromagnetic powders (i.e., $\mathrm{Co}, \mathrm{Fe}, \mathrm{Ni}$ ) with non-magnetic metals (e.g., $\mathrm{Au}, \mathrm{Cu}$, $\mathrm{Ag}$ ) gives rise to mechanical alloys with a giant magnetoresistance (GMR) effect. ${ }^{3}$ Since an addition of $\mathrm{Si}$ reduces the magnetic anisotropy and the eddy-current loss in commercial steels, Fe-Si mechanical alloys also received much interest. ${ }^{4-7}$ By contrast, $\mathrm{Co}-\mathrm{Si}$ alloys only gained attention in the last decade after being recognized as hydrogen-storage materials for nickel-metal hydride batteries. The discharge capacity and cycling ability of negative electrodes are reportedly improved when using 1 : 1 or $2: 1 \mathrm{Co}-\mathrm{Si}$ milled for $10-80 \mathrm{~h}^{8-10}$ In addition to homogenizing their sizes and shapes, the ball milling leads to several compounds as shown by the $\mathrm{Co}-\mathrm{Si}$ phase diagram. ${ }^{11}$ The $\mathrm{Co}_{2} \mathrm{Si}, \mathrm{CoSi}$ and $\mathrm{CoSi}_{2}$ phases affect the magnetic and hydrogen-storage properties of the alloys. ${ }^{10-14}$

In this work, the evolution of the phases during the initial period of the milling of Co with $x=60 \% \mathrm{Si}$ is examined. The thermal and magnetic properties of these Co-Si powders from the early stage of the ball-milling for up to $8 \mathrm{~h}$ are also reported.

\section{EXPERMENTAL WORK}

Elemental crystalline cobalt powder (a $99.8 \%$ purity with the average particle size of less than $2 \mu \mathrm{m}$ ) and silicon powder (a $99 \%$ purity with the average particle size of less than $44 \mu \mathrm{m}$ ) were mixed in an atomic ratio of $40: 60$ in a steel vial loaded with steel balls of $3 \mathrm{~mm}$ in diameter. The ball-to-powder mass ratio was around $15: 1$. The vial was spun at $595 \mathrm{r} / \mathrm{min}$ on a vario-planetary mill (Fritsch) for (2, 4, 6 and 8) h in a dry condition under air. The structural and magnetic properties of the milled powders were characterized with X-ray diffrac- 
tion $(\mathrm{XRD})$ using $\mathrm{Cu}-\mathrm{K} \alpha$ radiation and vibrating sample magnetometry (VSM), respectively. The coercive field was determined from the $\mathrm{x}$-intercept of the hysteresis loop obtained with VSM, whereas the y-intercept corresponded to the remanent magnetization. A ratio of the remanent magnetization to the saturation magnetization is referred to as the magnetic squareness in Table 1. The thermal properties were studied using a differential thermal analysis (DTA) with a heating rate of $5{ }^{\circ} \mathrm{C} \mathrm{min}-1$.

Table 1: Magnetic squareness and coercive field of $\mathrm{Co}-x(\mathrm{Si})=60 \%$ powders

Tabela 1: Magnetna kvadratnost in koercitivno polje prahov iz Co $x(\mathrm{Si})=60 \%$

\begin{tabular}{|c|c|c|}
\hline $\begin{array}{c}\text { Milling time } \\
(\mathrm{h})\end{array}$ & $\begin{array}{c}\text { Magnetic } \\
\text { squareness }\end{array}$ & $\begin{array}{c}\text { Coercive field } \\
\left(\mathrm{kA} \mathrm{m}^{-1}\right)\end{array}$ \\
\hline 2 & 0.28 & 15.15 \\
\hline 4 & 0.29 & 15.32 \\
\hline 6 & 0.28 & 15.48 \\
\hline 8 & 0.37 & 19.41 \\
\hline
\end{tabular}

\section{RESULTS AND DISCUSSION}

The XRD patterns of the Co-Si powders after the milling shown in Figure $\mathbf{1}$ have characteristic peaks of the fcc Si phase $\left(2 \theta=28.440^{\circ}, 47.300^{\circ}\right.$ and $\left.56.120^{\circ}\right)$ and the hcp Co phase $\left(2 \theta=47.220^{\circ}, 44.080^{\circ}\right.$ and $41.440^{\circ}$ ). According to the literature ${ }^{15}$, allotropic Co undergoes a transition from the hcp to the fcc structure at a temperature around $450{ }^{\circ} \mathrm{C}$. Previous works suggested that the ball milling can also induce such an allotropic transformation by virtue of a defect accumulation. ${ }^{16-19}$ The mixed phase may be converted into a highly distorted hcp structure in the early stage of milling but further milling leads to a fcc structure as a result of the stacking faults from the plastic deformation. ${ }^{17}$ The CoSi and $\mathrm{CoSi}_{2}$ phases are not clearly detected. The formation of silicide compounds generally requires prolonged milling and, as demonstrated with $\mathrm{Pd}-\mathrm{Si}^{1}$, it is dependent

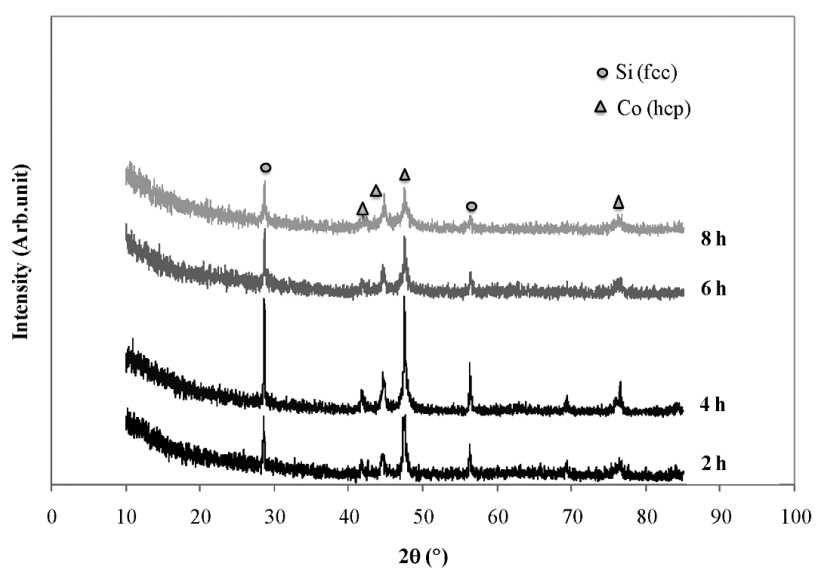

Figure 1: XRD patterns of $\mathrm{Co}-x(\mathrm{Si})=60 \%$ powders after milling for $2-8 \mathrm{~h}$

Slika 1: XRD-posnetki prahov $\mathrm{Co}-x(\mathrm{Si})=60 \%$ po mletju od $2 \mathrm{~h}$ do $8 \mathrm{~h}$ on the volume fractions of the two elemental powders. In some cases, the milling is carried out at a high temperature to stimulate the formation of compounds. ${ }^{1}$ In our case, all $\mathrm{Co}$ and $\mathrm{Si}$ peaks are rather sharp indicating a high degree of crystallinity. However, the peaks clearly broaden and their intensities are decreased after the milling for $8 \mathrm{~h}$. The small peaks of Si slightly below $70^{\circ}$ in the case of milling for $2 \mathrm{~h}$ and $4 \mathrm{~h}$ disappear after the longer milling.

The morphologies of the $\mathrm{Co}-\mathrm{Si}$ powders at various milling times obtained with SEM are shown in Figure 2. After the milling for $2 \mathrm{~h}$, several particles are still bulky, with straight and sharp edges. The edges are gradually broken or rubbed off and the particles become smoother as the milling progresses. Furthermore, the particle size is clearly reduced after the longest milling time of $8 \mathrm{~h}$. It was also reported that a decrease in the particle size of $\mathrm{Fe}-\mathrm{Si}$ powders began to be noticeable only after $5 \mathrm{~h}$ of ball milling. ${ }^{7}$ It is known that milling modifies the size of ball-milled powders by virtue of fracturing and cold welding. Each process dominates in a different stage of milling and the welding of particles is dominant in the initial milling time of up to $3 \mathrm{~h} .^{5,6}$ The narrower size distribution seen in the case of $8 \mathrm{~h}$ milling is a result of simultaneous fracturing of larger particles and cold welding of smaller particles. The powder from the early stage of milling can be modeled as brittle $\mathrm{Si}$ embedded in more ductile Co particles.

It is seen from the DTA curves in Figure 3 that after $2 \mathrm{~h}$ to $8 \mathrm{~h}$ of milling, the samples exhibit a broad exothermic peak centered around $600{ }^{\circ} \mathrm{C}$. The area is increased with the milling time because more energy is released in the case of prolonged milling. Another exothermic peak is observed that was shifted from above to
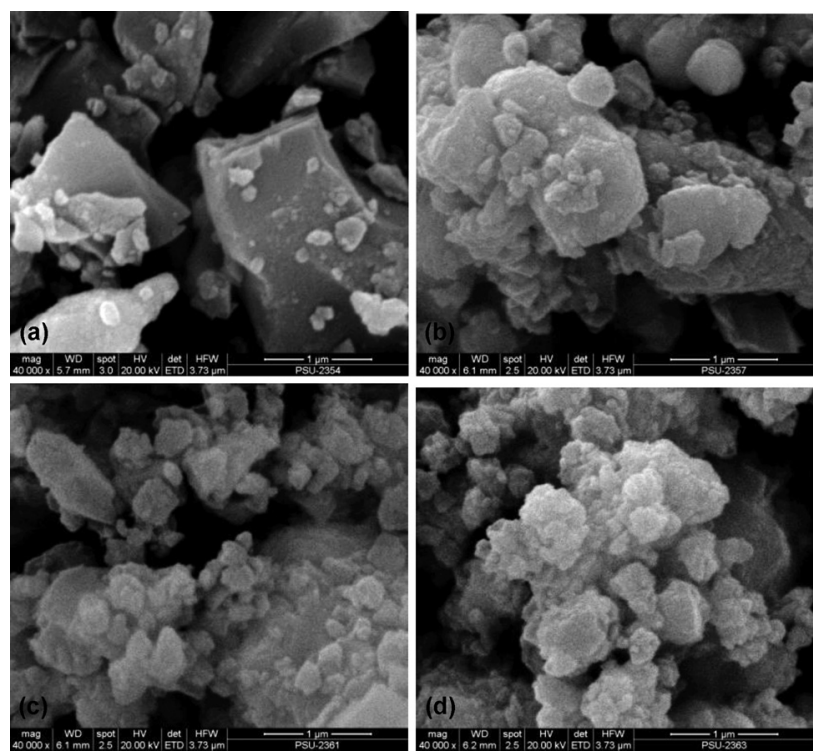

Figure 2: SEM micrographs of $\mathrm{Co}-x(\mathrm{Si})=60 \%$ powders after milling for: a) $2 \mathrm{~h}$, b) $4 \mathrm{~h}$, c) $6 \mathrm{~h}$ and d) $8 \mathrm{~h}$

Slika 2: SEM-posnetki prahov $\mathrm{Co}-x(\mathrm{Si})=60 \%$ po mletju: a) $2 \mathrm{~h}, \mathrm{~b})$ $4 \mathrm{~h}, \mathrm{c}) 6 \mathrm{~h}$ in d) $8 \mathrm{~h}$ 


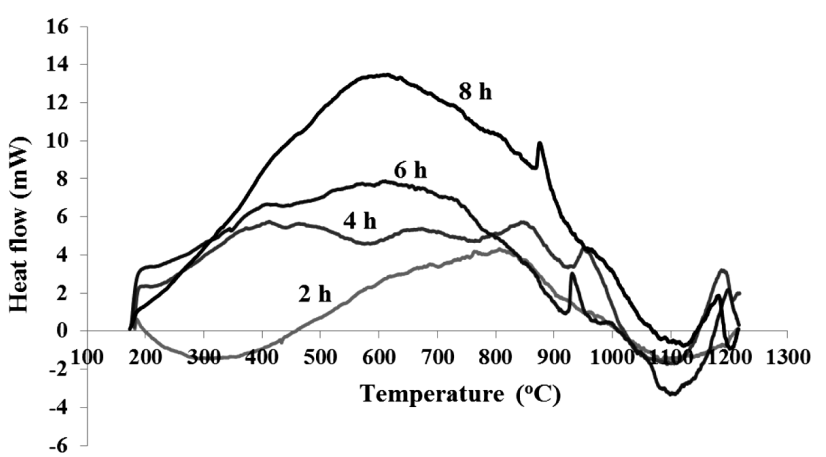

Figure 3: DTA curves of $\mathrm{Co}-x(\mathrm{Si})=60 \%$ powders after milling for 2-8 h

Slika 3: DTA-krivulje prahov $\mathrm{Co}-x(\mathrm{Si})=60 \%$ po mletju od $2 \mathrm{~h}$ do $8 \mathrm{~h}$

below $900{ }^{\circ} \mathrm{C}$ due to the increase in the milling time. This small exothermic peak may correspond to the ferromagnetic-to-paramagnetic transition. In addition to both exothermic peaks, there are endothermic peaks at around $1100{ }^{\circ} \mathrm{C}$ corresponding to the melt appearing in the system and at around $450{ }^{\circ} \mathrm{C}$ resembling the transition from hcp to fcc in bulk Co. ${ }^{15}$ The latter is less notable in the case of a longer milling time because the defect accumulation due to milling already facilitates the transformation to the fcc phase. The heat absorption also reduces the defect and dislocation density in the lattice-recovery process at around $200-300{ }^{\circ} \mathrm{C}$ which is clearly detected only in the case of $2 \mathrm{~h}$ milling.

The hysteresis loops of the milled Co-Si powders are shown in Figure $\mathbf{4}$ and their magnetic parameters are summarized in Table 1. Like the other granular Co alloys $^{3}$, the magnetization is not saturated under the magnetic field of about $200 \mathrm{kA} \mathrm{m}^{-1}$. Both the coercive field and squareness (approximated from the ratio of the remanence to the maximum magnetization in $200 \mathrm{kA} \mathrm{m}^{-1}$ ) remain rather constant in the case of $2-6 \mathrm{~h}$ milling but increase significantly after the milling for $8 \mathrm{~h}$. Interestingly, the size of Co particles is slightly modified during the $2-6 \mathrm{~h}$ milling. This can then be related to the dependence of the magnetic properties on the particle size of magnetic mechanical alloys. The coercive field is also related to the lattice imperfections as the milling is progressed because they impede the domain-wall movement. ${ }^{4,5}$ Although Co has a strong crystalline anisotropy $^{20}$, it is noted that these coercive-field values are comparable to those of the Fe alloys with a high fraction of $\mathrm{Si}$, which could be further reduced with heat treatments. ${ }^{5,7}$

\section{CONCLUSION}

The ball-milling of Co $-60 \% \mathrm{Si}$ for up to $8 \mathrm{~h}$ does not significantly induce silicide and amorphous phases. However, there are some modifications in the morphology and particle size during this early stage of milling. As a result, the thermal and magnetic properties of

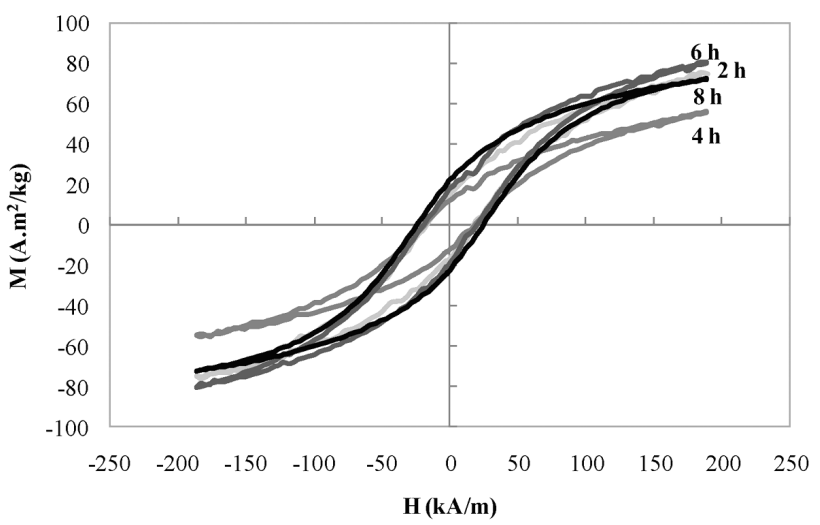

Figure 4: Hysteresis loops of $\mathrm{Co}-x(\mathrm{Si})=60 \%$ powders after milling for $2-8 \mathrm{~h}$

Slika 4: Histerezne zanke prahov Co $-x(\mathrm{Si})=60 \%$ po mletju od $2 \mathrm{~h}$ do $8 \mathrm{~h}$

Co-Si powders are considerably influenced by the milling time. In addition to the endothermic DTA peaks corresponding to the lattice recovery, the allotropic Co transition, the melting and the ferromagnetic-to-paramagnetic transition give rise to an exothermic peak, which shifts to a lower temperature as the milling progresses. The considerable reduction in the particle size after the milling for $8 \mathrm{~h}$ results in an enhanced coercive field and magnetic squareness.

\section{Acknowledgements}

This work was funded by Faculty of Science, Kasetsart University (ScRF-E5-2553). The authors would like to thank Scientific Equipments Center, Prince of Songkla University for the characterization facilities and Jureeporn Noodam for her assistance in the characterizations.

\section{REFERENCES}

${ }^{1}$ D. L. Zhang, Processing of advanced materials using high-energy mechanical milling, Progress in Materials Science, 49 (2004), 537-560, doi:10.1016/S0079-6425(03)00034-3

${ }^{2}$ K. Ociepka, A. Bajorek, A. Chrobak, G. Chelkowska, K Prusik, Magnetic properties of $\mathrm{Tb}\left(\mathrm{Ni}_{1-\mathrm{x}} \mathrm{Fe}_{\mathrm{x}}\right)_{3}(\mathrm{x}=0.2,0.6)$ crystalline compounds and powders, Acta Physica Polonica A, 126 (2014) 1, 180-181, doi:10.12693/APhysPolA.126.180

${ }^{3}$ W. Rattanasakulthong, C. Sirisathitkul, Effects of oxidation and cluster distribution on thermal and magnetotransport properties of mechanically alloyed Co-Cu powders, Applied Physics A, 83 (2006) 1, 77-81, doi:10.1007/s00339-005-3455-2

${ }^{4}$ T. J. Zhou, Z. Yu, Y. W. Du, The effective magnetic anisotropy in nanocrystalline $\mathrm{Fe}_{100-\mathrm{x}} \mathrm{Si}_{\mathrm{x}}$ alloys, Journal of Magnetism and Magnetic Materials, 202 (1999) 2-3, 354-358, doi:10.1016/S0304-8853(99) 00384-4

${ }^{5}$ J. Ding, Y. Lee, L. F. Chen, C. R. Deng, Y. Shi, Y. S. Chow, T. B. Gang, Microstructure and soft magnetic properties of nanocrystalline Fe-Si, Journal of Alloys and Compounds, 314 (2001) 1-2, 262-267, doi:10.1016/S0925-8388(00)01234-2

${ }^{6}$ B. Zuo, N. Saraswati, T. Sritharan, H. H. Hng, Production and annealing of nanocrystalline $\mathrm{Fe}-\mathrm{Si}$ and $\mathrm{Fe}-\mathrm{Si}-\mathrm{Al}$ alloy powders, Materials Science and Engineering A, 371 (2004) 1-2, 210-216, doi:10.1016/j.msea.2003.11.046 
${ }^{7}$ S. H. Kim, Y. J. Lee, B. H. Lee, K. H. Lee, K. Narasimhan, Y. D. Kim, Characteristics of nanostructured $\mathrm{Fe}-33$ at.\%Si alloy powders produced by high-energy ball milling, Journal of Alloys and Compounds, 424 (2006) 1-2, 204-208, doi:10.1016/j.jallcom.2005.10. 085

${ }^{8}$ G. He, L. F. Jiao, H. T. Yuan, Y. Y. Zhang, Y. J. Wang, Preparation and electrochemical hydrogen storage property of alloy CoSi, Electrochemistry Communications, 8 (2006) 10, 1633-1638, doi:10.1016/ j.elecom.2006.07.023

${ }^{9}$ Y. Zhang, L. Jiao, Y. Wang, Q. Wang, Y. Zhang, L. Liu, H. Yuan, Influence of $\mathrm{CoSi}$ on the electrochemical hydrogen storage properties of $\mathrm{MgNi}$ alloy, International Journal of Hydrogen Energy, 33 (2008) 18, 4819-4823, doi:10.1016/j.ijhydene.2008.05.098

${ }^{10}$ Y. Wang, J. M. Lee, X. Wang, An investigation of the origin of the electrochemical hydrogen storage capacities of the ball-milled Co-Si composites, International Journal of Hydrogen Energy, 35 (2010) 4, 1669-1673, doi:10.1016/j.ijhydene.2009.12.026

${ }^{11}$ H. Okamoto, Co-Si (Cobalt-Silicon), Journal of Phase Equilibria and Diffusion, 29 (2008) 3, 295, doi:10.1007/s11669-008-9311-2

${ }^{12}$ J. S. Tsay, Y. D. Yao, Y. Liou, Magnetic phase diagram study of ultrathin $\mathrm{Co} / \mathrm{Si}(111)$ films, Surface Science, $454-456$ (2000) $1-2$, 856-859, doi:10.1016/S0039-6028(00)00158-8

${ }^{13}$ S. W. Kim, Y. Mishima, D. C. Choi, Effect of process conditions on the thermoelectric properties of CoSi, Intermetallics, 10 (2002) 2, 177-184, doi:10.1016/S0966-9795(01)00122-4
${ }^{14}$ S. Abhaya, G. V. Rao, S. Kalavathi, V. S. Sastry, G. Amarendra, Silicide formation in $\mathrm{Co} / \mathrm{Si}$ system investigated by depth-resolved positron annihilation and X-ray diffraction, Surface Science, 600 (2006) 13, 2762-2765, doi:10.1016/j.susc.2006.04.043

${ }^{15}$ C. Xie, J. Hu, R. Wu, H. Xia, Structure transition comparison between the amorphous nanosize particles and coarse-grained polycrystalline of cobalt, Nanostructured Materials, 11 (1999) 8, 1061-1066, doi:10.1016/S0965-9773(99)00394-3

${ }^{16}$ J. Y. Huang, Y. K. Wu, H. Q. Ye, K. Lu, Allotropic transformation of cobalt induced by ball milling, Nanostructured Materials, 6 (1995) 5-8, 723-726, doi:10.1016/0965-9773(95)00160-3

${ }^{17}$ J. Sort, J. Nogués, S. Suriñach, M. D. Baró, Microstructural aspects of the hcp-fcc allotropic phase transformation induced in cobalt by ball milling, Philosophical Magazine, 83 (2003) 4, 439-455, doi:10.1080/0141861021000047159

${ }^{18}$ M. Baricco, N. Cowlam, L. Schiffini, P. P. Macrí, R. Frattini, S. Enzo, Copper-cobalt f.c.c. metastable phase prepared by mechanical alloying, Philosophical Magazine B, 68 (1993) 6, 957-966, doi:10.1080/13642819308217953

${ }^{19}$ F. Cardellini, G. Mazzone, Thermal and structural study of the h.c.p.-to-f.c.c. transformation in cobalt, Philosophical Magazine A, 67 (1993) 6, 1289-1300, doi:10.1080/01418619308225355

${ }^{20}$ T. H. Lee, H. C. Koo, H. Kim, S. H. Han, S. H. Lim, Crystalline anisotropy effect on magnetic properties and its competition with shape anisotropy, Metals and Materials International, 17 (2011) 3 , 509-513, doi:10.1007/s12540-011-0632-z 